Electronic Waste Recycling Campaign at Universidad San Francisco de Quito, Ecuador

Denisse Dalgo ${ }^{1,2}$, Valeria Ochoa-Herrera ${ }^{1,2 *}$, Gabriela Pérez $^{2}$, René Parra $^{2}$, Ródny Peñafiel ${ }^{2}$, Mateo Sáenz ${ }^{1}$, Alexandra Velasco ${ }^{1,3}$

${ }^{1}$ Universidad San Francisco de Quito, Oficina de Innovación y Sustentabilidad (OIS-USFQ), Diego de Robles y Via Interoceánica, Quito, Ecuador.

${ }^{2}$ Universidad San Francisco de Quito, Colegio de Ciencias e Ingenierías, Diego de Robles y Vía Interoceánica, Quito, Ecuador.

${ }^{3}$ Universidad San Francisco de Quito, Colegio de Administración y Economía, Diego de Robles y Via Interoceánica, Quito, Ecuador.

*Autor principal/Corresponding author,e-mail: vochoa@usfq.edu.ec

Editado por/Edited by: Cesar Zambrano, Ph.D.

Recibido/Received: 2015/10/15. Aceptado/Accepted: 2015/11/10.

Publicado en línea/Published on Web: 2015/12/30. Impreso/Printed: 2015/12/30.

\begin{abstract}
The increasing consumption of technological products may have serious implications due to the worldwide generation of abundant electronic devices that can become contaminating electronic waste or e-waste after their lifespan. This is due to the hazardous nature of some of their components. In Ecuador, despite the presence of some recycling companies and the governmental policies that attempt to establish an appropriate electronic waste management, much must still be done at public and private level in order to implement e-waste recycling and thus avoid the generation of these hazardous waste. In this study we present the results for the first Electronic Waste Recycling Campaign carried out at Universidad San Francisco de Quito, Ecuador, on which the university community and the civil society cooperated. A total of $1.89 \mathrm{t}$ of e-waste were gathered and more than a half of these materials were intended for recycling or reuse within the country or internationally. The main electronic waste gathered included laptops, CRT monitors, keyboards, tablets, CPU, UPS for PC, mouse, PC speakers, wired for power and ICD monitors. Flow charts were made using VENSIM software, basing the calculation on one unit of each electronic waste. This recycling campaign is the first one organized by an Academic Institution in Ecuador and therefore provides useful information about the role that higher education institutions can play in such sustainable initiatives.
\end{abstract}

Keywords. Electronic waste, recycling campaign, waste management, sustainability, university, Ecuador.

\title{
Campaña de Reciclaje de Residuos Electrónicos en la Universidad San Francisco de Quito
}

\section{Resumen}

El aumento del consumo de productos tecnológicos podría tener serias implicaciones debido a la abundante producción de equipos electrónicos a nivel mundial. Estos equipos pueden afectar el medio ambiente ya que pueden convertirse en residuos electrónicos o chatarra electrónica cuando han cumplido su vida útil debido a la naturaleza contaminante de algunos de sus componentes. En Ecuador, a pesar de la presencia de empresas recicladoras y de las políticas gubernamentales que intentan establecer un manejo adecuado de residuos electrónicos, mucho falta por hacer a nivel público y privado para implementar el reciclaje de residuos electrónicos y así eliminar la generación de este tipo de contam-inantes peligrosos. En este estudio se presenta los resultados de la primera Campaña de Residuos Electrónicos llevada a cabo en la Universidad San Francisco de Quito en la que intervinieron tanto la comunidad universitaria como la sociedad. $1.89 \mathrm{t}$ de residuos elec-trónicos fueron recolectados y más de la mitad de estos materiales fueron destinados para reciclaje o reutilización a nivel nacional o internacional. Los principales artículos recolec-tados fueron laptops, monitores CRT, teclados, tablets, CPU, memorias externas para PC, mouse, parlantes para PC, cables de poder y monitores. Diagramas de flujo fueron real-izados utilizando el software VENSIM, asumiendo como base de cálculo una unidad de cada residuo electrónico. Esta campaña de reciclaje es la primera organizada por una insti-tución académica en Ecuador y por lo tanto proporciona información útil sobre el rol que las instituciones de educación superior pueden desarrollar en la consecución de iniciativas sustentables.

Palabras Clave. Residuos electrónicos, campaña de reciclaje, manejo de residuos, sustentabilidad, universidad, Ecuador. 


\section{Introduction}

The technological era we are living in is characterized by an increasing consumption of computers and electronic devices. As long as new technologies are brought to market, the previous obsolete devices are left in disuse and become electronic waste [13]. The concept of electronic waste or e-waste comprises those technological products whose useful life has ended. These electronic devices also constitute electronic parts that are external or internal to the equipment and that become waste for its malfunction or its obsolete components [17]. Most of the electronic waste is discarded with household trash because people ignore or disregard the hazardous materials that electronic waste contains [9]. E-waste consists of approximately 60 chemical elements, including precious metals and hazardous materials that, if not treated properly, release lethal toxins into atmosphere, water, and soil [10] and therefore can cause serious problems to the environment and human health [19].

E-waste contains metals and persistent organic pollutants (POPs) [9, 17]. When e-waste is incinerated several toxins can be released into the biosphere, such as furans, polycyclic aromatic hydrocarbons (PAHs), hydrogen chloride, and dioxin [10]. Inappropriate recycling processes mostly occur in developing countries because of the low cost of labor and the permissiveness of environmental laws and as a result, these toxicants are being released into the environment causing several problems to some populations [9, 17].

Both scientists and policy makers are recognizing with increasing conviction the potential significance of the pollution caused by e-waste [3]. Many studies evidence the health risks that affect populations encountering the toxins from electronic devices [10]. For example, air and soils of the Chinese population of Guiyu are heavily contaminated with toxic substances emitted into the atmosphere and with chemicals originating in electronic goods or generated by the dangerous disposal of nonrecyclable components [21]. Higher serum lead levels in the inhabitants suggest that populations like Guiyu are being affected by lead-discarded electronics and by open, uncontrolled, burning of e-waste [10].

Some estimates claim that each year 20 to 25 million $\mathrm{t}$ of e-waste are generated worldwide, equivalent to 3.5 to $4 \mathrm{~kg}$ of e-waste per inhabitant per year [10, 17]. Nevertheless, the United Nations Environment Programme UNEP estimates that each year the world produces 50 million tons of electronic waste, causing damage to the environment due to its toxic level [1, 18, 19]. According to the Environmental Protection Agency [6], the amount of e-waste discarded daily worldwide is 142000 computers and approximately 416000 cell phones. The final destination of $70 \%$ of global electronic waste is unknown [17], which is worrisome given the high toxicity of the pollution that this waste generates when not properly discarded.
On the other hand, in Latin America and the Caribbean the amount of e-waste reaches about $800000 \mathrm{t}$ and Argentina, Brazil, Chile, Colombia, Mexico and Venezuela are the countries that together produce more than $80 \%$ of e-waste in the region [1].

Industrially, different metallurgical routes are used to extract valuable metals from e-waste. In fact, e-waste recycling means taking an electronic product at the end of its useful life in order to use the whole or part of its components to make another product [4]. Electronic recycling represents an excellent and attractive alternative for environmental protection and for the recovery of reusable materials and precious metals such as gold $(\mathrm{Au})$, silver $(\mathrm{Ag})$, platinum $(\mathrm{Pt})$, Gallium $(\mathrm{Ga})$, palladium $(\mathrm{Pd})$, tantalum $(\mathrm{Ta})$, tellurium $(\mathrm{Te})$, germanium (Ge) and selenium (Se) [8]. Overall, energy consumption for the recycling process is less than that required for the development of a new product [6]. Additionally, during the process of electronic recycling, the emissions of $\mathrm{CO}_{2}$ and $\mathrm{SO}_{2}$ are reduced, and the waste generated during the development of new products is avoided [20].

On January 2013, in the Official Gazette No. 881, the Environmental Ministry of Ecuador issued its National Post Consumer Policy of Electrical and Electronic Equipment which establishes as general objective to apply the principle of responsibility and public participation in the management of electrical and electronic equipment whose useful life has ended [14]. This policy prohibits the disposal of electrical and electronic equipment, which can be recycled or treated under environmentally friendly conditions. It also requires the State to inform the population about the alternatives for e-waste management [14]. However, most people in Ecuador still know little about e-waste management options in order to not discard electronic waste with regular garbage. There are no official data on the amount of technological waste generated or its final destination. For this reason, the Office of Innovation and Sustainability in conjunction with the Student Government of the Universidad San Francisco de Quito (USFQ) organized the first Electronic Waste Recycling Campaign in order to encourage the university community to gather different types of electronic waste, to allocate them to recycling companies and thus contribute to reduce pollution.

The aim of this study was to document the results achieved through this campaign at USFQ. An estimate of the quantity and types of recyclable materials that could be recovered from the collected e-waste was performed by means of modeling and theoretical data in order to know the contribution of this campaign to the e-waste recycling process. Finally this estimate was compared with the actual results at the end of the campaign. Recycling and final disposal of electronic waste collected at USFQ were modeled based on the information provided by the private Ecuadorian companies PRODES, BIORECICLAR and ANDEC. 


\section{Methods}

The Electronic Waste Recycling Campaign consisted on a competition between the different Faculties of the USFQ, on which the winner was the Faculty that contributes with the biggest amount of electronic waste per student. The different faculties of the USFQ and the number of students that belong to each one of them are shown in Table 1 .

The Electronic Waste Recycling Campaign was carried out from November 14th to 20th, 2014. During these days, both members of the university community and people of the civil society in general attended two different e-waste collection points to deliver disused electronic devices. One e-waste collection point was located inside the University in Cumbayá, Ecuador and several posters promoting the campaign were placed in different strategic points of the campus. Considering that previous experience of converting shopping malls into e-waste collection points have been successful [2], the other collection point was settled down in the shopping mall "Paseo San Francisco" located near the university campus.

Electronic devices of different types were gathered as CPUs, LCDs, screens, monitors, UPSs, keyboards, laptops, tablets, chargers, wires, cellular phones, batteries, printers, scanners, headphones, mp3, walkmans, discmans, speakers, among others. A number of weighting points was assigned to each type of electronic device (Table 2). This number was based on two considerations: the amount of recyclable elements that constitutes each type of e-waste and the effort that involved delivering each type of e-waste for recycling rather than throwing it away.

Thereafter, each Faculty earned a total quantity of points depending on the amount and types of electronic waste provided by their students during the Electronic Waste Recycling Campaign. Because some faculties have more students than the others and this implies more possibilities of collecting e-waste, the winner Faculty was determined by obtaining the average of points earned per

\begin{tabular}{ccc}
\hline Faculty & $\begin{array}{c}\text { Number of } \\
\text { students }\end{array}$ & $\begin{array}{c}\text { Percentage } \\
(\boldsymbol{\%})\end{array}$ \\
\hline POLITECNICO & 1236 & 20.6 \\
CADE & 967 & 16.1 \\
COCISOH & 742 & 12.4 \\
COCSA & 724 & 12.1 \\
COCOA & 686 & 11.4 \\
CADI & 554 & 9.2 \\
JURISPRUDENCIA & 333 & 5.5 \\
COM & 309 & 5.1 \\
COCIBA & 256 & 4.3 \\
CHAT & 197 & 3.3 \\
\hline TOTAL & 6004 & 100.0 \\
\hline
\end{tabular}

Table 1: Faculties of the USFQ and number of students for each Faculty that participated in the Electronic Waste Recycling Campaign.

\begin{tabular}{cc}
\hline Electronic Waste & Points \\
\hline Batteries & 1 \\
Keyboards & 2 \\
Chargers/wires & 3 \\
Headphones & 5 \\
LCD/screens/monitors & 10 \\
Speakers & 15 \\
Cell phones & 20 \\
mp3/walkman/discman & 20 \\
Others & 20 \\
Tablets & 25 \\
Printers/scanners & 25 \\
Laptops & 30 \\
CPU & 50 \\
UPS & 50 \\
\hline
\end{tabular}

Table 2: Weighting points assigned to each type of e-waste during Electronic Waste Recycling Campaign.

student (per capita) in each Faculty and not by the total amount of points. The winner was rewarded with a prize and public recognition.

During the campaign it was not possible to weigh all items received; therefore, the environmental manager PRODES provided an average weight of each type of electronic device (Table 3). An estimate of the total weight of e-waste was calculated multiplying the collected number of each type of device by its average weight. This estimation was then compared with the actual value of e-waste delivered to BIORECICLAR, the environmental manager in charge of the final disposition of e-waste at the end of the campaign.

Additionally, PRODES provided data of the percentage of materials like steel, aluminum, copper, plastic, etc. present in each electronic device and data of the proportion of these materials that must be disposed to the landfill or that can be recycled or reused nationally and internationally. This information is shown in Table 3 and was used to elaborate a mass balance of the electronic waste, to obtain flowcharts and to estimate the total of materials that would be recovered from the total amount of e-waste collected.

With the total amount of each type of electronic devices obtained, an estimate of the quantity of materials that could be recovered and recycled was processed by means of the simulation software VENSIM 6.3 and an Excel spreadsheet.

The VENSIM software was used to provide flowcharts based on the data of the spreadsheet, and thus graphically display the inflow and outflow of electronic waste. Moreover, the weights of copper, aluminum, iron and other recovered elements were based on information provided by PRODES.

\section{Results}

At the end of the campaign, the estimated total amount of e-waste gathered was $1.89 \mathrm{t}$ of electronic e-waste delivered by the USFQ. Table 4 presents the final amount 


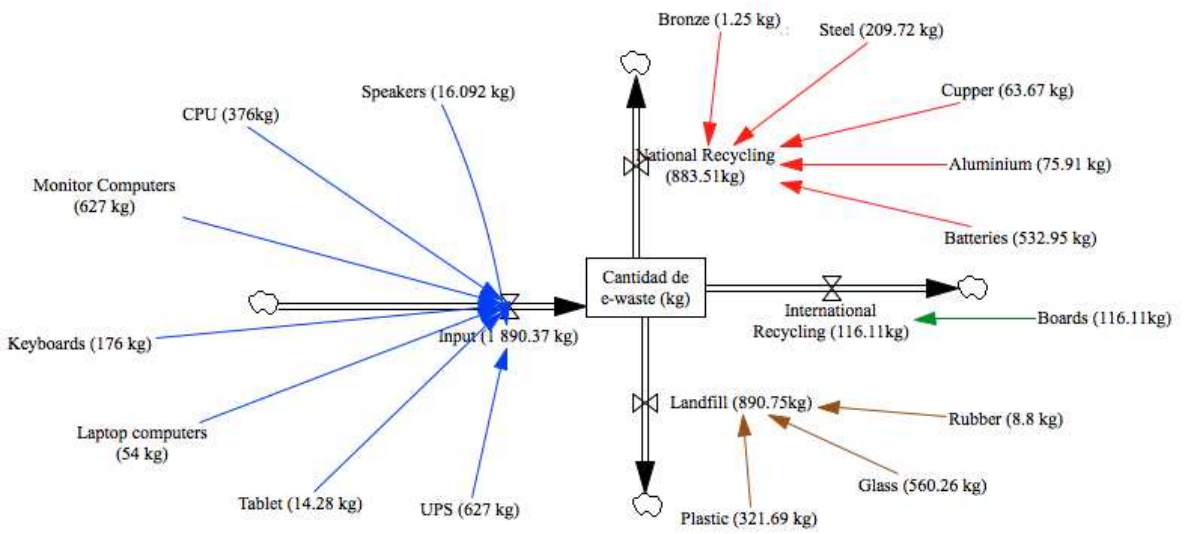

Figure 1: Flow chart of the electronic waste collected during the campaign. The inputs (in weight) of the different types of e-waste are shown with the blue arrows. The outputs (in weight) are shown with red arrows for national recycling, green arrows for international recycling and brown arrows for landfill as final destiny.

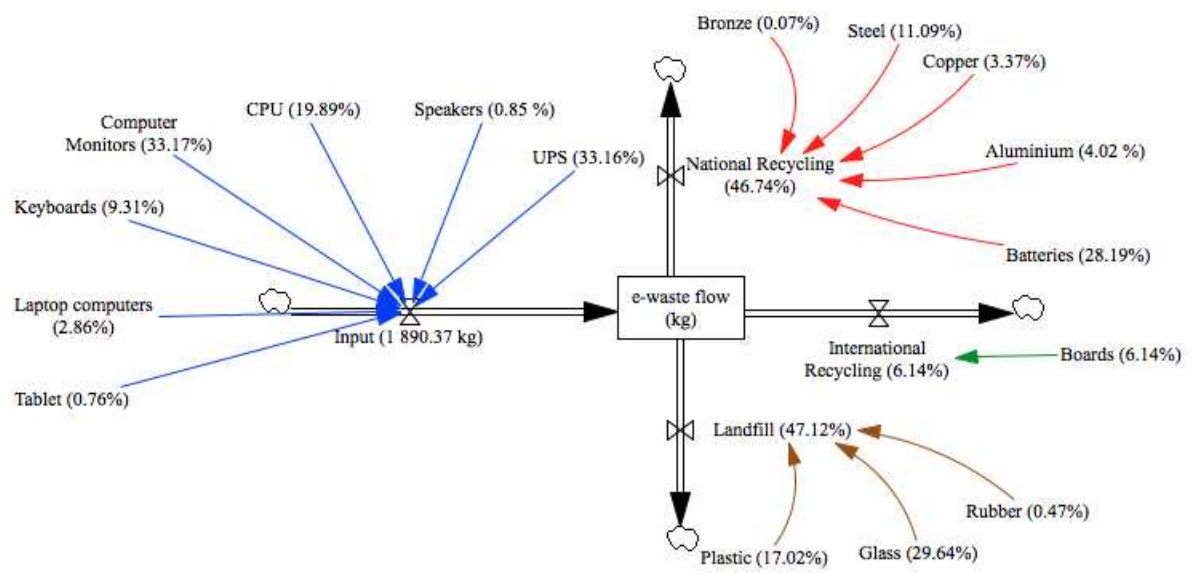

Figure 2: Flow chart of the electronic waste collected during the campaign. The inputs (in percentage) of the different types of e-waste are shown with the blue arrows. The outputs (in percentage) are shown with red arrows for national recycling, green arrows for international recycling and brown arrows for landfill as final destiny.

of each type of e-waste collected during only 7 days of the Electronic Waste Recycling Campaign at USFQ.

Figures 1 and 2 show flow charts modeled with VENSIM software. These diagrams illustrate, in weight (Figure 1) and percentage (Figure 2), the input flow of each type of device collected. As can be observed in the figures, the total input was $1890.37 \mathrm{~kg}$ of e-waste, including speakers, CPUs, monitors, keyboards, laptops, tablets and UPSs.

The output flow corresponds to the different allocations that were given to the electronic waste depending on the materials recovered. $46.74 \%$ of the materials was intended for recycling or reuse within the country and $6.14 \%$ was intended for recycling or reuse abroad. Unfortunately, $47.12 \%$ of the materials where destined to the landfill with common waste but at least $650 \mathrm{~kg}$ of plastic, $50 \mathrm{~kg}$ of glass and $10 \mathrm{~kg}$ of wood were managed with the company Arte Green for the elaboration of crafts. More than half of the collected e-waste was destined for recycling or reuse processes. Ferrous materials were destined to "Empresa de Acerías Nacionales de Ecuador" ANDEC, National Industry where the final destination is the production of raw steel ingots (billets) and construction rods (Prodes). Non ferrous materials like bronze, steel, copper, aluminum and batteries were delivered to the company RECYNTER S.A.

Figure 3 shows the flowcharts modeled with VENSIM software for the different materials to be obtained in the process of collecting electronic waste such as bronze, batteries, steel, boards, glass, copper, aluminum, rubber and plastic.

Regarding the competition between USFQ Faculties, as can be seen in Table 5, the Faculty of Biological and Environmental Sciences COCIBA obtained the highest amount of points per capita (30.8 points/student), followed by the College of Science and Engineering POLI TÉCNICO (8.4 points/student).

\section{Discussion}

The number of companies that have an environmental license for treatment and recycling of e-waste in Ecuador is still low; in fact, the first e-waste recycling company was established in the country just in 2012 [16]. Because of the lack of advanced technologies, part of ewaste produced in the country must be exported for its final disposal. The collected materials that cannot be 


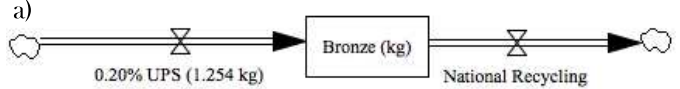

b)
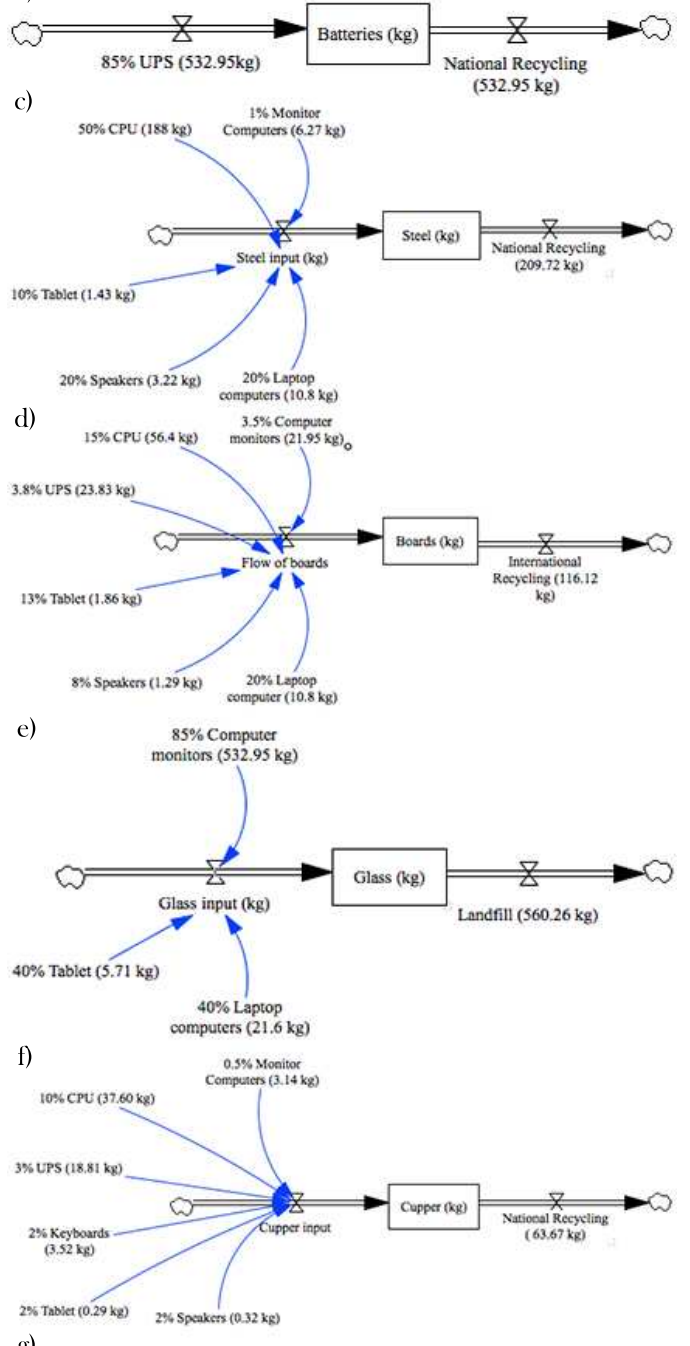

g)

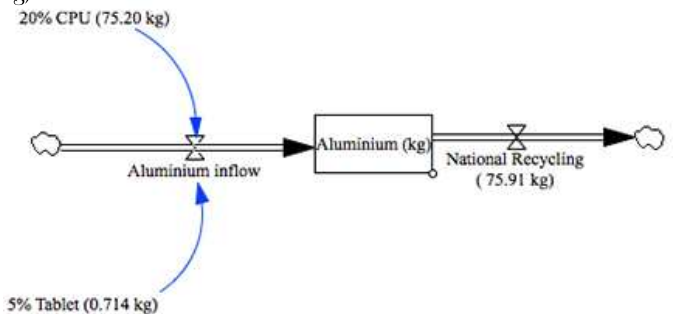

h)
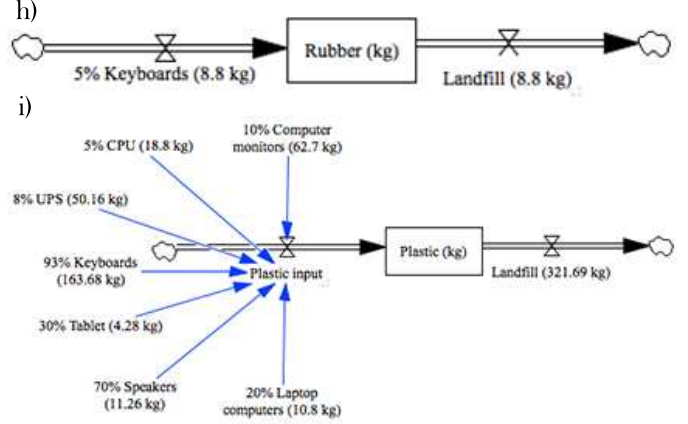

Figure 3: Flowcharts for different materials from electronic waste: A. Bronze, B. Batteries, C. Steel, D. Boards, E. Glass, F. Copper, G. Aluminum, H. Rubber and I. Plastic. Blue arrows show the different sources from which the materials are recovered and the arrow of the right shows the final disposal of each material. 


\begin{tabular}{|c|c|c|c|c|}
\hline Material & $\begin{array}{c}\text { Average } \\
\text { Weight (kg) }\end{array}$ & $\begin{array}{c}\text { Percentage of } \\
\text { recyclable } \\
\text { materials to be } \\
\text { processed in } \\
\text { Ecuador }(\%) \\
\end{array}$ & $\begin{array}{c}\text { Percentage of non- } \\
\text { recyclable } \\
\text { materials }(\%)\end{array}$ & $\begin{array}{c}\text { Percentage of } \\
\text { recyclable } \\
\text { materials to be } \\
\text { processed abroad } \\
(\%)\end{array}$ \\
\hline Laptop & 1.80 & 20 of steel & $\begin{array}{l}40 \text { of glass, } \\
20 \text { of plastic }\end{array}$ & 20 of mainboard \\
\hline Monitor CRT & 11.00 & $\begin{array}{c}1 \text { of steel } \\
0.5 \text { of copper }\end{array}$ & $\begin{array}{c}85 \text { of glass } \\
10 \text { of plastic }\end{array}$ & 3.5 of mainboard \\
\hline Tablet & 0.68 & $\begin{array}{l}10 \text { of steel, } \\
5 \text { of aluminum, } \\
2 \text { of copper }\end{array}$ & $\begin{array}{l}40 \text { of glass, } \\
30 \text { of plastic }\end{array}$ & 13 of mainboard \\
\hline $\mathrm{CPU}$ & 8.00 & $\begin{array}{c}50 \text { of steel, } \\
10 \text { of copper, } \\
20 \text { of aluminum }\end{array}$ & 5 of plastic & $\begin{array}{l}15 \text { of mainboard } \\
\text { (memory) }\end{array}$ \\
\hline Monitor LCD & 4.00 & $\begin{array}{c}30 \text { of steel, } \\
0.5 \text { of copper }\end{array}$ & 60 of plastic & 9.5 of mainboard \\
\hline Charger & 0.25 & 40 of copper & 60 of rubber & \\
\hline Keyboard & 0.50 & 2 of copper & $\begin{array}{c}93 \text { of plastic, } \\
5 \text { of rubber }\end{array}$ & \\
\hline Mouse & 0.20 & 2 of copper & $\begin{array}{c}89 \text { of plastic, } \\
5 \text { of rubber }\end{array}$ & 4 of mainboard \\
\hline Speakers & 0.29 & $\begin{array}{c}2 \text { of copper } \\
20 \text { of steel }\end{array}$ & 70 of plastic & 8 of mainboard \\
\hline UPS & 11.00 & $\begin{array}{c}85 \text { of batteries, } \\
3 \text { of copper, } \\
0.2 \text { of bronze }\end{array}$ & 8 of plastic & 3.8 of mainboard \\
\hline
\end{tabular}

Table 3: Composition of different electronic devices and their possible allocation. Information provided by PRODES.

processed inside the country must be processed by International Managers that are accredited for the extraction of precious metals like gold, silver and platinum. For example, Sitekol-Colombia processes mainboards and Codelco-Chile melts copper wires. The final destination for these materials is the production of metal ingots that are used in the medical field for amalgam and tooth pieces according to the information provided by PRODES. They are also intended for jewelry making and in the space field for the construction of satellites and ferries and processing of copper cathodes. On the other hand, the rest of the materials was destined to landfills. This is because, although some of the ewaste components are recovered, most of these devices are composed of non-recyclable glass, plastic or rubber, which is destined for landfills. However, it was possible to divert a fraction of non-recyclable materials towards the development of arts and crafts.

Finding efficient collection and appropriate technologies for recycling e-waste is especially difficult in developing countries [15]. Even in countries that count with advanced treatment equipment and technologies, finding an efficient collection system is a limiting aspect to an appropriate e-waste management [15]. Consequently, this type of campaign contributed by introducing an e-waste collection system in the university community and separating the most toxic and polluting e-waste materials. Moreover, this first Electronic Waste Recycling Campaign created awareness among college students of the importance of the proper disposal of ewaste.

Besides the environmental concerns, e-waste collecting and processing implies energy savings and resource efficiency [8]. Therefore, campaigns like this should be replicated at the public and private level. Previously, in the public sector, the Governmental Institution of Telecommunications developed a campaign of Electronic Waste Recycling and Collection of batteries in order to promote the importance of proper management of electronic waste [12]. In the private sector there are some companies that are dedicated to the collection, dismantling and recovery of certain materials from electronic waste, other appliances and scrap in order to obtain some profit. Mobile phone companies in Ecuador have also organized campaigns in order to promote recycling. Cell phones are among the electronic devices most consumed in Ecuador, a market that has expanded during the last decade. These campaigns consist of gathering electronic devices and then exporting them to the United States where materials such as copper and silver can be recovered [11]. However, these campaigns only cover devices like phones, batteries and accessories of mobile phones; therefore it is more difficult to find incentives or information about an appropriate place to deposit other types of electronic waste.

During this first Electronic Waste Recycling Campaign organized by the USFQ, through its Office of Innovation and Sustainability, it was evidenced that Universi- 


\begin{tabular}{cc}
\hline Type of electronic devices & Total (Units) \\
\hline Batteries & 5065 \\
Chargers/wires & 1418 \\
Cell phones & 267 \\
Headphones & 196 \\
Printers/scanners & 115 \\
Keyboards & 100 \\
LCDs/screens/monitors & 57 \\
mp3/walkman/discman & 54 \\
Speakers & 54 \\
CPU & 47 \\
Laptops & 30 \\
Tablets & 21 \\
UPS & 16 \\
\hline
\end{tabular}

Table 4: Total number of units collected by type of electronic waste during Electronic Waste Recycling Campaign.

ties are important leaders when promoting initiatives for sustainability because they are able to spread the knowledge and skills necessary to engage in activities related to Sustainable Development [7]. The competition between Faculties was an extra incentive for students to contribute. The Faculty that contributed the most during the campaign and therefore that scored the highest amount of points per student was the Faculty of Biological and Environmental Sciences which suggests that, in general, students whose programs of study are related to the environment showed higher commitment to the environment; therefore contributed the most with the campaign. According to Edumadze et al. studentsŠacademic backgrounds influenced their awareness on ewaste [5]. It is also imperative the necessity of the inclusion of environmental education in university curricula. It should not only be included in scientific programs but also in different areas of specialization in general with courses related to e-waste hazards and e-waste management [5].

Educational institutions are frequently applying shifts in technology and it results in a large number of discarded devices after short periods of lifespan [13]. For this reason Universities are appropriate places to gather disused electronic devices. As evidenced in this study, university students and staff contribute greatly to the recycling process. On the other hand, malls are frequented places and therefore the effort and time consumed to deliver e-waste is reduced. Furthermore, Çetinsaya et al. identified other advantages of shopping malls for e-waste campaigns like being safe and public places where marketing campaigns related with electronic products are mounted [2]. However, in this study the e-waste collected at "Paseo San Francisco" was significantly lower as compared to the amount collected at the University campus.

Modeling and flow charts predicted the amount of recoverable materials from the different types of e-waste collected. Therefore, they are very good options applicable to other similar campaigns to predict and determine their success. The estimation and modeling of the

\begin{tabular}{cc}
\hline Faculty & Points per capita \\
\hline COCIBA & 30.80 \\
POLITECNICO & 8.34 \\
CADI & 8.25 \\
COCISOH & 7.11 \\
CADE & 4.75 \\
COCOA & 3.73 \\
COM & 3.04 \\
CHAT & 2.78 \\
JURISPRUDENCIA & 1.65 \\
COCSA & 0.91
\end{tabular}

Table 5: Final Results of the Electronic Waste Recycling Campaign.

e-waste flow were comparable to the actual values resulting at the end of the E-waste Recycling Campaign. Universities and other institutions of education must establish a cooperation network with other private and public institutions in order to replicate these campaigns periodically. For future e-waste campaigns the main focus should not only be recycling, as Walters and Santillo propose, reducing must also be promoted and governmental support and legislation is required to prevent use of hazardous substances in electronics and to increase the participation and responsibility of producers and importers [21]. At the same time appropriate recycling technologies should be the mainstay of e-waste recycling practices.

\section{Conclusions}

The campaign organized by the USFQ, through its Office of Innovation and Sustainability and the support of their students and the community in general, is the first electronic waste recycling campaign conducted at the level of an academic institution in Ecuador. The support received by this campaign as well as its results showed that citizens share a general impetus to contribute to such sustainable initiatives that seek to reduce global pollution. USFQ plans to develop this campaign every year and will use this case study as an initial insight for further investigation and for gathering new and more data related to e-waste.

\section{Acknowledgments}

We are very thankful to the members of Student Government of USFQ and to the university community in general who actively participated in this first Electronic Waste Recycling Campaign at USFQ. Special thanks to Melanie Valencia for reading this manuscript and providing valuable insights.

\section{References}

[1] Barreiro, E.; Winicki, M. 2010. "Los residuos electrónicos: Un desafío para la Sociedad del Conocimiento en América Latina y el Caribe: Gestión de residuos electrónicos". La visión del Plan CEIBAL en Uruguay. UNESCO Montevideo, Günther Cyranek, y Chile Plataforma RELAC SUR/IDRC Uca Silva. 
[2] Çetinsaya Özkir, V.; Efendigil, T.; Demirel, T.; Çetin Demirel, N.; Deveci, M.; TopÇu, B. 2015. "A threestage methodology for initiating an effective management system for electronic waste in Turkey". Resources, Conservation and Recycling, 96: 61-70.

[3] Chen, A.; Dietrich, K. N.; Huo, X.; Ho, S. 2011. "Developmental Neurotoxicants in ?-Waste: An Emerging Health Concern". Environmental Health Perspectives, 119(4).

[4] Chibunna, J. B.; Siwar, C.; Mohamed, A. F.; Begum, R. A. 2013. "The role of university in E-waste recycling: Case of University Kebangsaan Malaysia". Research Journal of Applied Sciences, 8(1): 59-64.

[5] Edumadze, J. K. E.; Tenkorang, E. Y.; Armah, F. A.; Luginaah, I.; Edumadze, G. E. 2013. "Electronic waste is a mess: Awareness and proenvironmental behavior among university students in Ghana". Applied Environmental Education and Communication, 12(4): 224-234.

[6] EPA. 2013. U.S. Environmental Protection Agency. www.epa.gov.

[7] Ferrer-Balas, D.; Adachi, J.; Banas, S.; Davidson, C. I.; Hoshikoshi, A.; Mishra, A.; Ostwald, M. 2008. "An international comparative analysis of sustainability transformation across seven universities". International Journal of Sustainability in Higher Education, 9(3): 295-316.

[8] Khaliq, A.; Rhamdhani, M. A.; Brooks, G.; Masood, S. 2014. "Metal Extraction Processes for Electronic Waste and Existing Industrial Routes: A Review and Australian Perspective". Resources, 3: 152-179.

[9] Ladou, J.; Lovegrove, S. 2008. "Export of Electronics Equipment Waste". INternational Journal of Occupational and Environmental Health, 14(1): 1-10.

[10] Massey, K. A.; Eunsonb, J. 2010. "Electronic Wastelands: Decomposing Computers and Communities Around the World". UBCMJ, 2(1).

[11] Merino, D. 2010. "Gestión De Desechos Electrónicos De Mayor Generación En La Ciudad De Loja”. Proyecto final Ing. en Electrónica y Telecomunicaciones. Universidad Técnica Particular de Loja (UTPL): $1-90$.

[12] Ministerio de Telecomunicaciones y Sociedad de la Información. 2014. "MINTEL participó con Campaña de Reciclaje de residuos electrónicos en la feria "Vivamos con valores 2014 Scouts Ecuador' ". http://www.telecomunicaciones.gob.ec/ mintel-participo-con-campana-de-reciclaje-del -residuos-electronicos-en-la-feria-vivamos-/ con-valores-2014-scouts-ecuador/

[13] Odhiambo, B. D. 2009. "Generation of e-waste in public universities: The need for sound environmental management of obsolete computers in Kenya". Waste Management, 29(10): 2788-2790.

[14] Política Nacional Post Consumo de Equipos Eléctricos y Electrónicos. 2013. Acuerdo Ministerial N 190. Registro Oficial No. 881.
[15] Qu, Y.; Zhu, Q.; Sarkis, J.; Geng, Y.; Zhong, Y. 2013. "A review of developing an e-wastes collection system in Dalian, China". Journal of Cleaner Production, 52: 176-184.

[16] Reliche, A. 2012. "Con licencia ambiental se abrió la primera planta de reciclaje de desechos electrónicos del país". Agencia pública de noticias del Ecuador y Suramérica. http://www.andes.info.ec/es/sociedad/ 5752.html.

[17] Robinson, B. H. 2009. "E-waste: an assessment of global production and environmental impacts". The Science of the Total Environment. 408(2): 183 Ü91.

[18] UNEP. 2005. "E-waste, the hidden side of IT equipment's manufacturing and use". Environmental Alert Bulletin, 5: 1-3.

[19] UNEP. 2013. "Storage and disposal of mercury in Mexico and Panama". UNEP in Latin America and the Caribbean Newsletter, 6.

[20] USGS. 2001. "Obsolete Computers, 'Gold Mine', or High-Tech Trash?". Resource Recovery from Recycling. USGS Fact Sheet FS-060-01: 1-4.

[21] Walters, A.; Santillo, D. 2008. "Evidence of environmental and health impacts of electronics recycling in China: an update". Greenpeace International, 4: 1-12. 